\title{
Impairment of female Oreochromis niloticus fecundity exposed to Butachlor herbicide
}

\author{
Manal A. A. Essa ${ }^{1 *}$, M. S. Marzouk ${ }^{2}$, Nashwa S. Elias ${ }^{3}$, Maysa H. Shaker ${ }^{4}$, Ghada \\ M. A. Mohamed ${ }^{4}$ \\ ${ }^{1}$ Department of Fish, Faculty of Veterinary Medicine, Beni-Suef University, Beni-Suef,62511, Egypt, \\ ${ }^{2}$ Department of Fish Diseases and Management, Faculty of Veterinary Medicine, Cairo University, \\ Cairo, Egypt, ${ }^{3}$ Department of Fish Diseases, Animal Health Research Institute, Giza, Egypt and ${ }^{4}$ \\ Department of Pathology, Animal Health Research Institute, Giza, Egypt.
}

Female Oreochromis niloticus were exposed to 1/10 LC50 $(0.21 \mathrm{ppm})$ of butachlor herbicide for 6 weeks. Weekly specimens were taken for fecundity estimation. Also hormonal and enzymatic levels were determined in addition histopathological alterations in ovaries and liver were detected. Butachlor exerted drastic effects on absolute and relative fecundity. Sex hormones (testosterone " $T$ " and estradiol " $E_{2}$ ") dropped significantly. The high significantly decline in Total Ripen Egg Number was assisted by the coagulative necrosis and oocytic atrasia in ovaries. In addition, thrombus formation and hepatoadenocarcinoma were pronounced in the liver and resulted in the significant drop in ALT and total protein levels. So, it is recommended to apply the biological control of pests in substitution to herbicids in rice fields.

Egypt is considered the second largest producer of tilapia in the world, where Nile tilapia accounts for about $80 \%$ of fish production. However, increasing knowledge about factors regulating fish productivity is of a great importance to achieve further development of tilapia culture Tahoun et al. (2008). Recently, Fitzsimmons (2008) admitted that Tilapia industry in Egypt to be a player in international trade needs an image of environmental awareness.

Environmental pollution due to extensive usage of the pesticides without proper management has affected on the survival potential of fish as some of these toxic chemicals may persist in the environment for long periods Gill et al. (1988). The major sources of environment contamination by these chemicals are agriculture practices usage in public health programs Hazarika and Das (1998). Through producing many physiological and biochemical changes in freshwater organisms they cause alterations in the physiological systems of the inhabitants particularly those of the fish Khan and Law (2005). The latter authors proved that at low concentrations, pesticides may act as blockers of sex hormones, causing abnormal

\footnotetext{
* Corresponding author. Tel.: +20 0127439416 ; Fax:+20 822327982

E-mail address: essa.maa@bsu.edu.eg (Manal A. A. Essa)
}

sexual development and unusual mating behavior. The chronic exposure to low levels of pesticides may have a more significant effect on fish populations than acute poisoning. In females; they caused delayed oocyte development and inhibition of steroid hormone synthesis. Chronic effects can be caused by the accumulation of pesticides in an organism's tissue.

Butachlor 2-chloro-2', 6'-diethyl-N [butoxymethyl] acetanilide is the most popular herbicide used to control weeds in transplanted rice paddy fields and absorbed into soil where it will disappear in irrigation water. However, still a minor amount of the herbicide could be detected in paddy drainage water even several weeks after application. Also, Butachlor had an antiestrogenic effect whereas it binds to estrogen receptors and exhibits estrogenic activity Wany et al. (1992) and Stephen (2001).

Sole et al. (2003) had proved an increase in plasmatic and hepatic vitellogenin (VTG), sex hormones ( $\mathrm{T}$ and E2) in wild carp Cyprinus carpio collected from a polluted area. Martinez et al. (2007) had found the role of sex steroid hormones ( $\mathrm{T}$ and E2) on the humeral immune parameters of teleost giltheads (seabream sparus aurate). Martinovic et al. (2008) reported that exposure of Fathead minnow (Pimephales promelas) to the fungicide Vinclozolin, using a 21-days reproduction assay caused decreased expression of male secondary sexual 
characteristics, impaired reproductive success and elicited endocrine responses consistent with an anti-androgenic mode of action.

Therefore, the present study was planned to study the effect of chronic exposure to butachlor herbicide on the fecundity, hormonal and enzymatic functions in adult female $O$. niloticus.

\section{Materials and methods}

Fish Collection. A total of one hundred forty apparently healthy females $O$. niloticus with an average body weight of $120 \pm 30 \mathrm{~g}$ and total length 19-22 cm. were collected from a brood stock pond in a private farm, Sharkia Governorate and transported to Fish Diseases Department at Animal Health Research Institute with least delay in large plastic bags with battery aerators. Fish inspection was carried out to exclude those with abnormalities then kept a week for acclimation under laboratory conditions at $25 \pm 2{ }^{\circ} \mathrm{C}$. Random specimens from ovaries were examined microbiologically and parasitologically to make sure that they were negative to bacterial, fungal or parasitic infections.

Butachlor Herbicide. N-butoxymethyl 2chloro-2', 6'-diethyl acetanilide was produced by El-Helb Company at Domiatt governorate. Butachlor is a light yellow to purple liquid with a faint sweet odor soluble in most organic solvents including diethyl ether, acetone, benzene, ethanol, ethyl acetate and hexane.

Experimental Design. Fish were divided to seven groups of 20 fish each.

A dose of $1 / 10 \quad$ LC50 $0.21 \mathrm{ppm}$ concentrations from the Butachlor was applied to six groups leaving one as a control according to Mohamed (2009).

Samples were taken from all groups after 7 ,
14, 21, 28 and 42 days.

Clinical Picture. Full inspection of fish throughout the experimental period was carried to record all clinical signs and postmortem lesions.

Fecundity Estimation. Growth measurements and morpho-anatomical parameters were calculated for each fish.

Relative and absolute fecundity were determined through microscopical examination of each ovary according to Elias and Abd EL Halim (2009).

Biochemical Parameters. After serum separation from blood samples of each fish total protein (T.P), Liver enzymes (AST and ALT) and sex hormones ( $T$ and $E_{2}$ ) were measured for each fish by ELISA technique using kits according to Ismail et al. (1972) and Tietz (1995) respectively.

Histopathological Examination. Ovaries and liver samples from each group under test were placed in Bouin's solution for 48 hours before being prepared, for histopathology (Takashima and Hibiya, 1995).

Statistical Analysis Systems (SAS). The obtained data were statistically analyzed using Program version 9.1, Satistical

Analysis System (2005) institute incorporation, Cary, NC 27513 USA

\section{Results}

Most recorded clinical signs appeared in form of abnormal skin pigmentation (darkening), excessive mucous secretion on skin and the most prominent signs were skin ulceration, detached scales with fin and tail rot (photo 1). Whereas postmortem findings revealed congestion and hemorrhages in all internal organs with ovarian and liver discoloration (photo 2).

Table (1): Comparative fecundity of $O$. niloticus female exposed to chronic toxicity with butachlor (Mean \pm SD).

\begin{tabular}{|c|c|c|c|c|c|c|c|}
\hline & & Control & 7 Days & 14 Days & 21 Days & 28 Days & 42 Days \\
\hline & B.L. (cm.) & $21 \pm 0.7$ & $22 \pm 1$ & $19 \pm 1$ & $21 \pm 1$ & $22 \pm 1$ & $19 \pm 0.3$ \\
\hline Growth & B.W. (g ) & $120 \pm 1$ & $134 \pm 2^{1}$ & $98 \pm 4^{3}$ & $125 \pm 4$ & $146 \pm 2^{3}$ & $103 \pm 3^{3}$ \\
\hline \multirow[t]{3}{*}{ Measurements } & $\mathrm{W}_{\mathrm{G}}(\mathrm{g})$ & $3 \pm 0.4$ & $3.1 \pm 1$ & $2.6 \pm 0.3$ & $1.2 \pm 0.1^{3}$ & $1.8 \pm 0.3^{2}$ & $2 \pm 0.1^{2}$ \\
\hline & $\mathrm{W}_{\mathrm{H}}(\mathrm{g})$ & $1.5 \pm 0.2$ & $2.8 \pm 0.3^{3}$ & $1.5 \pm 0.2$ & $1.5 \pm 0.1$ & $2 \pm 0.3^{2}$ & $1.9 \pm 0.1$ \\
\hline & $\mathrm{I}_{\mathrm{G}}$ & $1.8 \pm 0.3$ & $2.3 \pm 0.4$ & $2.7 \pm 0.2^{2}$ & $1.0 \pm 0.1^{2}$ & $1.5 \pm 0.2$ & $2.9 \pm 0.5^{3}$ \\
\hline \multirow{4}{*}{$\begin{array}{l}\text { Morpho-anatomical } \\
\text { parameters }\end{array}$} & $\mathrm{I}_{\mathrm{H}}$ & $1.3 \pm 0.04$ & $2.1 \pm 0.1^{3}$ & $1.8 \pm 0.04^{3}$ & $1.4 \pm 0.1$ & $1.7 \pm 0.1$ & $1.8 \pm 0.1^{3}$ \\
\hline & FBL & $1252 \pm 6$ & $1459 \pm 1^{3}$ & $1073 \pm 8^{3}$ & $1172 \pm 4$ & $1480 \pm 1^{3}$ & $1100 \pm 3^{3}$ \\
\hline & FBW & $995 \pm 7$ & $952 \pm 1^{3}$ & $725 \pm 2^{3}$ & $754 \pm 2^{3}$ & $817 \pm 6^{3}$ & $751 \pm 2^{3}$ \\
\hline & FOW & $759 \pm 4$ & $888 \pm 5^{3}$ & $775 \pm 4^{2}$ & $628 \pm 4^{3}$ & $605 \pm 4^{3}$ & $802 \pm 4^{3}$ \\
\hline Absolute fecundity & T. R. Egg No. & $2583 \pm 5$ & $408 \pm 5^{3}$ & $494 \pm 4^{3}$ & $301 \pm 6^{3}$ & $600 \pm 4^{3}$ & $780 \pm 4^{3}$ \\
\hline
\end{tabular}

$\mathrm{N}=10 \quad{ }^{1} \mathrm{P}<0.05 \quad{ }^{2} \mathrm{P}<0.01 \quad{ }^{3} \mathrm{P}<0.001 \quad$ B.L.:- body length $\quad$ B.W:-body weight

$\mathrm{W}_{\mathrm{G}}$ :-gonadal weight $\quad \mathrm{W}_{\mathrm{H}}$ :- hepatic weight $\mathrm{I}_{\mathrm{G}}$ :- gonadosomatic index

$\mathrm{I}_{\mathrm{H}}$ :-hepatosomatic index

FBL:- fecundity related to body length

FBW:- fecundity related to body weight

FOW:- fecundity related to gonadal weight

T.R Egg No.:-total ripened egg number 
Table (2) Comparative biochemical parameters of O. niloticus female following chronic exposure to butachlor (Mean $\pm \mathrm{SD}$ ).

\begin{tabular}{lcccccc}
\hline $\begin{array}{l}\text { Biochemical } \\
\text { parameters }\end{array}$ & Control & $\mathbf{7}$ Days & 14 Days & 21 Days & 28 Days & 42 Days \\
\hline T.P. $(\mathbf{g} / \mathbf{d l})$ & $6.5 \pm 0.4$ & $2 \pm 0.1^{3}$ & $1.4 \pm 0.1^{3}$ & $1.5 \pm 0.3^{3}$ & $3.8 \pm 0.5^{3}$ & $7 \pm 0.1$ \\
AST $(\boldsymbol{\mu} / \mathbf{m l})$ & $35 \pm 3.0$ & $27 \pm 2.0^{1}$ & $24 \pm 1.0^{2}$ & $25 \pm 3.0^{1}$ & $32 \pm 3.0$ & $47 \pm 0.3^{3}$ \\
ALT $(\mathbf{g} / \mathbf{d l})$ & $17 \pm 0.5$ & $6 \pm 0.8^{3}$ & $5 \pm 0.3^{3}$ & $5 \pm 0.6^{3}$ & $4 \pm 0.3^{3}$ & $15 \pm 0.4$ \\
T( $\mathbf{~ g ~ / ~} \mathbf{~ m l )}$ & $6.8 \pm 0.03$ & $3.7 \pm 0.01^{3}$ & $5.1 \pm 0.8^{3}$ & $1.2 \pm 0.1^{3}$ & $3.3 \pm 0.3^{3}$ & $4.7 \pm 0.3^{3}$ \\
E2 $(\mathbf{n g} / \mathbf{m l})$ & $240 \pm 3.0$ & $150 \pm 3.0^{3}$ & $210 \pm 3.0^{3}$ & $230 \pm 5.0$ & $220 \pm 3.0$ & $215 \pm 2^{3}$ \\
\hline
\end{tabular}

$\mathrm{N}=10$

$$
{ }^{1} \mathrm{P}<0.05 \quad{ }^{2} \mathrm{P}<0.01 \quad{ }^{3} \mathrm{P}<0.001
$$

T.P:- Total protein $\quad$ AST:- Aspartate aminotransferase

ALT:- Alanine aminotransferase $\quad \mathrm{T}$ :-Testosterone E2:- 17ß-Estradiol
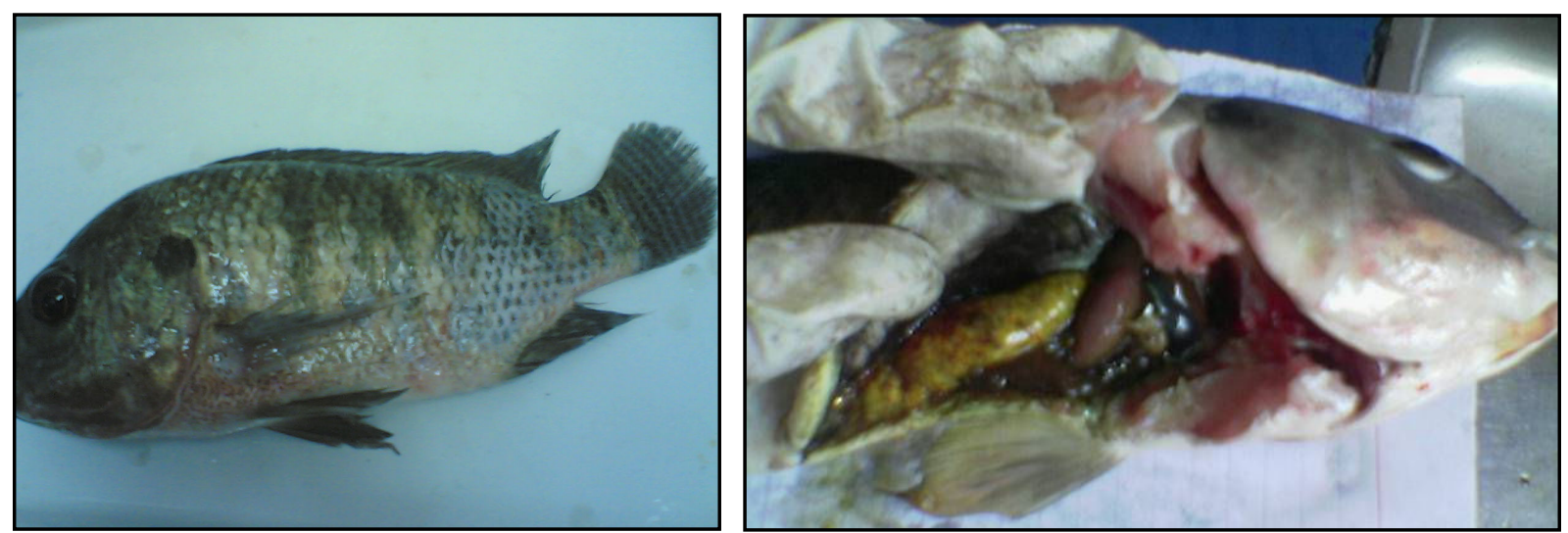

Photo (1): $\boldsymbol{O}$. niloticus exposed to chronic dose $(0.21 \mathrm{ppm}$.) of butachlor herbicide showing detached scales and skin ulceration with fin and tail rot.

Photo (2): $\boldsymbol{O}$. niloticus female exposed to chronic dose $(0.21 \mathrm{ppm})$ of butachlor herbicide showing patches of hemorrhages in ovary.
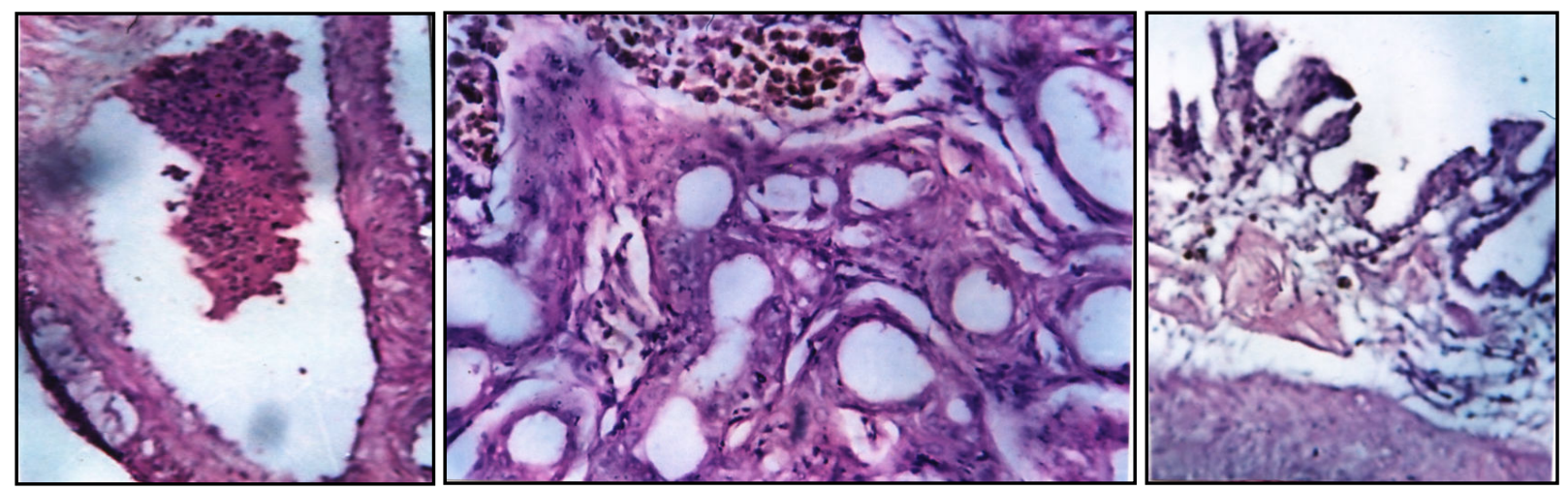

Fig. (1): Liver of $\boldsymbol{O}$. niloticus exposed to chronic dose $(0.21 \mathrm{ppm})$ of butachlor showing thrombus formation (H\&E stain X100).

Fig. (2): Liver of Female $\boldsymbol{O}$. niloticus exposed to chronic dose $(0.21 \mathrm{ppm})$ of butachlor herbicide showing hepatoadenocacinoma (H\&E stain X400).

Fig. (3): Ovary of $\boldsymbol{O}$. niloticus exposed to chronic dose $(0.21 \mathrm{ppm})$ of butachlor showing Leaf like projection appeared from granulose cells inwards (H\&E stain X200).

Clinical signs and postmortem findings. The most recorded clinical signs were abnormal skin pigmentation (darkening), excessive mucous secretion on skin, skin ulceration, detached scales with fin and tail rot (photo 1). In addition, postmortem findings include congestion and hemorrhages in all internal organs including ovary with liver discoloration (photo 2).

Histopathological alterations. Findings of ovaries and livers photocopied in figures $1-7$. 

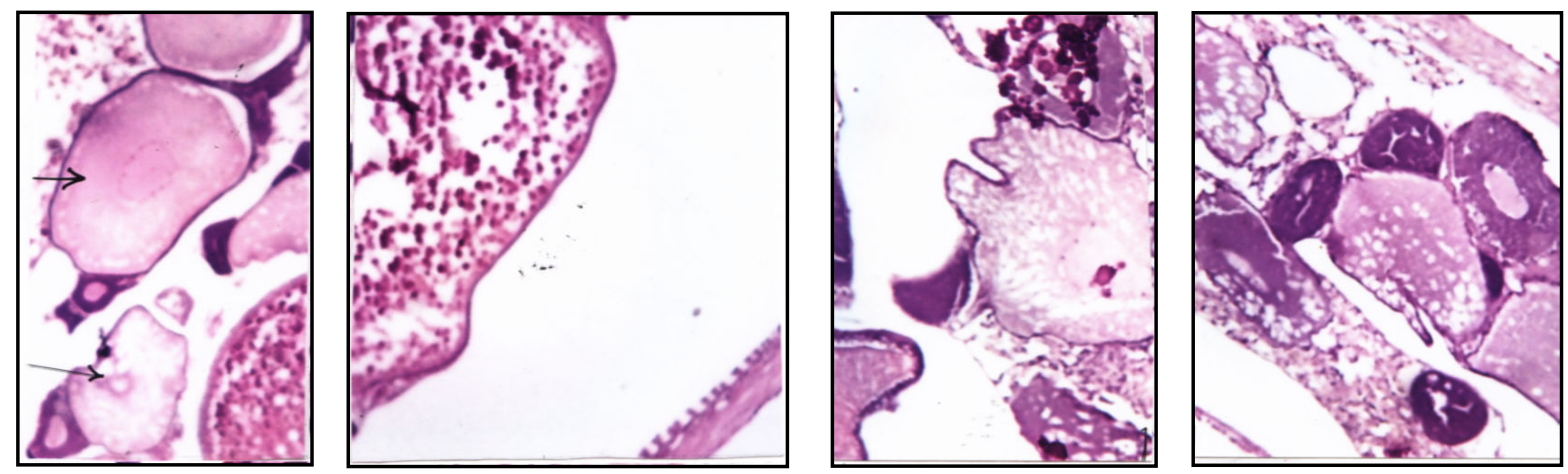

Fig. (4): Ovary of $O$. niloticus exposed to chronic dose $(0.21 \mathrm{ppm})$ of butachlor showing decrease in yolk formation (H\&E stain X100).

Fig. (5): Ovary of $O$. niloticus exposed to chronic dose (0.21 ppm) of butachlor showing oedema (H\&E stain X100).

Fig. (6 and 7): Ovary of $O$. niloticus exposed to chronic dose $(0.21 \mathrm{ppm})$ of butachlor herbicide showing collapsed of oocytes with oocytic atresia i.e. Irregularity in shape of oocystes (H\&E stain X100).

\section{Discussion}

Pollution of soil and water resources by pesticides is a pressing worldwide problem. The indiscriminate use of pesticides in agriculture causes environmental problems especially in the aquatic environment.

Culturing fishes in rice fields as integrated system was thought to be an excellent strategy, whereas Nile tilapia is commonly cultured in rice fields irrigated from the same water supply which is contaminated with pesticides.

Tarek (2007) and Radwan (2008) had revealed the existence of pesticides residues in various aquatic ecosystems. Moreover, Elnemeki and Abuzinadah (2003) knowing that fish can store about $58-93 \%$ of pesticides, they proved necrosis and hemorrhages in Oreochromis spilurus due to pesticide toxicity.

The chronic dose $(0.21 \mathrm{ppm})$ of Butachlor herbicide in the females O.niloticus showed the same clinical signs and postmortem findings as observed by Hasan (2005) who proved those short and long terms of Carbofuran herbicide exposure in $O$. niloticus led to abnormal swimming behavior, darkening of skin, detached scales with fin and tail rot and excessive mucous secretion photo 1 .

Exposing $O$. niloticus females to $0.21 \mathrm{ppm}$ of Butachlor herbicide for long term exposure revealed highly significant decrease in the ovarian weight throughout the whole experiment (Table, 1). El-Ashram (1999) had proved that since the production of eggs was the dominant function of an ovary, a close relationship could be expected between the ovarian weight and the number of ova produced. Seven days of exposure showed highly significant drop in relative fecundity as well as T.R. Egg No. This drop was explained by the histopathological alternations in ovaries which revealed hemorrhages between oocytes with oedema (Fig. 5). After 14 days of exposure, the highly significant decrease in T.R. Egg No. was attributed to the presence of intravascular hemolysis and dilatation of some ovarian blood vessels together with collapsed oocytes and oocytic atresia which prevented the formation of well mature ova full of vetillogenin (Fig., 4,6 \&7). Exposure for 21 days exerted highly significant decrease in ovarian weight as well as FOW which is due to clear proliferative changes in granulosa of most oocytes with leaf like projection appeared from granulose cells inwards resulting in adhesion of cellular coat and thickening of ovarian wall (Fig., 3). Female O. niloticus after 28 days showed irregular and collapsed oocytes, resulting in separation of follicular layers from the oocytes while the last group showed highly significant decrease in ovarian weight (WG) and T.R. Egg No. which was referred to the oocytic atrasia characterized by clumping and perforation of the chorion accompanied by disorganization of the ooplasm. Pathological changes recorded in this study is confirmed by Saravanan et al. (2003) who found that exposure of O. mossambicus to Endosulfan for 20 days exhibited degeneration of immature oocytes and rupture of follicular epithelium due to cell vacuolation, and necrosis. Also these results came in agreement with Coimbra et al. (2007) which recorded that exposure of $O$. niloticus to Endosulfan for 21 days induced hepatocyte destruction, vessel endothelium rupture and increased melanomacrophages aggregates.

Barakat (2004) had explained that fecundity drop was due to the effect of pollutants on fish reproduction and majority of the dissolved contaminants or their metabolites were 
monitored in fish as well as their spawning behavior, duration and fecundity. He added that the average number of eggs per spawning was also dropped among contaminated fish.

Proteins are involved in the architecture and physiology of the cell and in cell metabolism. Blood serum proteins were defined by Moustafa (1999) to be a fairly biochemical system, precisely reflecting the condition of the organism and its physiology under the influence of internal and external changes. However, serum protein decrease among the six groups exposed to butachlor was previously detected by Hanna and El-Maedawy (2007) and attributed to protein catabolism and hepatocellular damage due to herbicides or pesticides. Exposure to butachlor caused liver changes as thrombus formation and hepatoadinocarcinoma which is most prominent in the two last groups (Fig. 1 \&2). Hepatic damage was comprehensible reason for the highly significant drop in total serum protein levels Elias (2007).

The increase in aminotransferases activities might be attributed to the mobilization of amino acids into energy yielding pathways. The highly significant increase in liver enzyme (AST) of females' $O$. niloticus during last group of exposure was approved by Hasan (2005) who had recorded an increase in the level of the liver enzymes ALT and AST in O. niloticus exposed to Carbofuran for 30 days which was attributed to degeneration and destruction of hepatocytes. Through studying the effect of sublethal concentration of Metasyster and Sevin on freshwater teleost (Mystus vittatus), John (2007) had confirmed the increase of liver enzymes AST and ALT.

Among the other five groups of chronic toxicity with Butachlor herbicide females showed decrease in liver enzymes. Mousa (2004) and Shalaby et al. (2007) mentioned that liver enzymes decreased in serum due to Saturn and Glyphosate or Butachlor herbicide might be due to the decrease in the membrane permeability or inhibition of enzymes synthesis resulting from complete liver cells damage.

Mills et al. (2001) had classified chemicals as: DDT having an estrogenic effect showing depression of plasma $\mathrm{T}$ and vitellogenesis induction. On the contrary, Octylphenol being an anti-androgenic causing increased Estradiol, decreased Testosterone with no vitellogenin production. Jensen et al. (2004) proved that fathead minnow males exposed to short term Flutamide exhibited elevated concentration of 17 $\beta$ E2 hormone and vitellogenin. However, it could be suggested that Butachlor might be having an antiandrogenic mode-of-action similarly to Flutamide. It is an endocrine disruptor for fish sex hormones causing male to develop female characteristics accompanied by reduced fertility and even sterility in adults.

Spawning season is a period of steroidal superiority in fish gonads due to the action of pituitary gonadotropins. The levels of T and E2 should reach highest peak in females and males respectively to perform their role as biomarkers to identify gender

Steroidal hormonal values of $\mathrm{T}$ and $17 \beta \mathrm{E} 2$ among females exposed to Butachlor herbicide showed highly significant drop throughout the six periods of chronic exposure (Table 2). Steroidal drop coincides with the severe histopathological changes in the gonadal cells forming these hormones. In accordance, Singh and Canario (2004) had proved that $\mathrm{T}$ and $17 \beta$ E2 in both sexes had significantly declined in response to pesticide Y- hexachlorocyclohexane. Afterwards Singh and Singh (2007) had proved that 40 days exposure to DDT in catfish (Heteropneustes fossilis) resulted in $17 \beta \mathrm{E} 2$ levels decline.

The current study recommends that fish culturing of $O$. niloticus in rice fields should be applied with hygienic measures to prohibit Butachlor herbicide. Also, it attracts an attention to the necessity for applying biological control of pests and weeds in substitution to herbicides.

\section{References}

Barakat, K. K. (2004): Effect of some water pollutants on the biology of the Nile Bolti, Oreochromis niloticus. Pakistan. J. Biol. Sci., 73:305-308.

Coimbra, A. M.; Fernandes, A. F. and Henriques, M. A. R. (2007): Nile tilapia (Oreochromis niloticus), liver morphology, CYP1A activity and thyroid hormones after Endosulfan dietary exposure. Pesticide Biochem. Physiol., 89 (3): 230-236.

El-Ashram, M. A. (1999): Some reproductive studies one some freshwater fish with regard to some pathological and toxicological factors. Ph.D. Thesis Fac. Vet. Med. Zagazig Univ., Egypt.

Elias S. N. (2007): Steroidal fluctuations for wildlife normal Clarias gariepinus fecundity in comparison to those exposed to overdose or treatment dose of copper sulphate. Egypt. J. Aquat. Biol. \& Fish., (2007) Vol. 11, No. 3: 619 634.

Elias S. N. and Abd El Halim, S.S. (2009): Effect of Hydrogen Ion concentration $(\mathrm{Ph})$ fluctuations on Bacterial Infections and Fecundity of $O$. niloticus. Abbassa International Journal for Aquaculture, ISSN 1687-7683, Special Issue for Global Fisheries \& Aquaculture Research Conference, Cairo International Convention Center, $24-26$ October 2009 pp $819-834$.

Elnemeki, F. A and O. A. Abuzinadah. (2003): Effect of 
Contra/Insect 500/50 E. C. on the histopathology of Oreochromis spilurus fish. Bull. Nat. Inst. Oceanogr fish, A. R. E., 29:222-253.

Fitzsimmons, K. (2008): Tilapia product quality and new product forms for international markets. $8^{\text {th }}$ Inter. Symp. on Tilapia on Aquaculure., 8: 1-10.

Gill, S. T.; Pant, J. C. and Pant, J. (1988): Gill, liver, and kidney lesions associated with experimental exposures to Carbaryl and Dimethoate in the fish (Puntius conchonius) Ham. Bull. Environ. Contam. Toxicol., 41:71-78.

Hanna, M. I. and El-Maedawy, S. A. (2007): clinical and biochemical pictures of Carbofuran toxicity in Clarias gariepinus. J. Eviron. Sci., 33(2):67-91.

Hasan, R.E. (2005): Effect of Carbofuran toxicity on the health status of cultured Nile tilapia (Oreochromis niloticus). M.V.Sc. Thesis of Fish diseases and management Fac. Vet. Med. Cairo Univ., Egypt.

Hazarika, R. and Das, M. (1998): Toxicological impact of $\mathrm{BHC}$ on the ovary of the air-breathing catfish Heterpneustes fossilis (Bloch). Bull Environ. Contam. Toxico., 60 (1): 16-21.

Jensen, K. M.; Kahl, M. D.; Makynen, E. A.; Korte, J. J.; Leino, R. L.; Butterworth, B. C. and Ankley, G. T. (2004): Characterization of responses to the antiandrogen Flutamide in a short-term reproduction assay with the Fathead minnow. Aquat. Toxicol., 70 (2): 99-110.

John, J. P. (2007): Alteration of certain blood parameters of freshwater teleost Mystus vittatus after chronic exposure to Metasystox and Sevin. Fish. Physiol. Biochem., 33:1520.

Khan, M. Z. and Law, F. C. P. (2005): Adverse effects of pesticides and related chemicals on enzyme and hormone systems of fish, amphibians and reptiles. Proc. Pakistan Acad. Sci., 42 (4): 315-323.

Ismail, A. A.; Niswender, G. D. and Midgley, A. R. J. (1972): Clin. Endocr. Metab., 34:177-184.

Mohamed, G. M. A. (2009): Effect of exposure to butachlor on health status of cultured Oreochromis niloticus. M.Sc., Thesis, Fac. Vet. Med. Beni-Suef Uni., Egypt.

Martinez, G.; Arjona, J.F.; Garcia-Lopez, A.; Cuesta, V.C. L.; Esteban, A. M.; Mancera, M. J. and Rodriguez, M. J. (2007): Effect of sex-steroid hormones, testosterone and Estradiol, on humoral immune parameters of gilthead seabream. Fish and Shellfish Immunol., 23 (3): 693-700.

Martinovic, D.; Blake, L.S.; Durhan, E.J.; Greene, K.J.; Kahl, M.D.; Jensen, K.M.; Makynen, E.A.; Villeneuve, D.L. and Ankley, G.T. (2008): Reproductive toxicity of Vinclozolin in the Fathead minnow confirming an antiandrogenic mod of action. Environ. Toxicol. Chem., 27(2): 478-88.

Mills, L. J.; Gobell, R.G.; Haebler, R. A.; Borsay, D. H. J.; Jayaraman, S.; Pruell, J. R.; Mckinney, A. R.; Gardner ,G. R. and Zaroogian, G. E. (2001): Effect of estrogenic (o,p-DDT; Octylphenol) and anti-androgenic $(p, p$-DDE ) chemicals on indicators of endocrine status in
Juvenile male summer flounder (Paralichthys dentatus). Aqua. Toxicol., 52 (2):157-176.

Mousa, M. A. (2004). Toxicological studies on the effect of machete herbicide on some fish species. Egypt. J. Appl. Sci., 19 (5): 1-11

Moustafa, S. E. (1999): Effect of some insecticides on freshwater fish. Ph. D. Pharma., Zagazig Univ., Egypt.

Radwan, O.A. (2008): Monitoring of some pesticide residues in water and fish tissue samples collected from three locations at Sharkia governorate, Egypt. J. BiolChem. Environ. Sci., 3 (1): 583-597.

Saravanan, T.S.; Chandrasekar, R.; and Mohamed, M.N. (2003): Endosulfan induced changes in liver and ovary of the freshwater fish, Oreochromis mossambicus (Trewaves). Malaysian J. Sci., 22 (2): 29-34.

Shalaby, A.M.; Mousa, M.A. and Tag El Dain, H.A. (2007). Toxicological Effect of Butotaf herbicide on some physiological aspects and reproductive performance in Nile tilapia, Oreochromis niloticus. Egypt. J. Aqua. Biol. Fish, 11 (2): 145- 163.

Singh, P.B. and Canario, A.V. (2004): Reproductive endocrine disruption in the freshwater catfish, Heteropneustes fossilis, in response to the pesticide gammahexachlorocyclohexane. Ecotoxicol. Environ. Safety, 58 (1):77-83.

Singh, P.B. and Singh, V. (2007): Endosulfan induced changes in phospholipids in the freshwater catfish, Heteropneustes fossilis (Bloch). J. Environ. Boil., 28(3): 605-10.

Sole, M.; Raldua, D.; Piferrer, F.; Barcelo, D. and Porte, C. (2003): Long-term exposure effects in vitellogenin, sex hormones, and biotransformation enzymes in female carp in relation to a sewage treatment works. Ecotoxicol. Environ. Safety, 56 (3):373-380.

Stephen, H. (2001). Hydroylated polychlorinated Biphenyls (PCBs) and organochlorine pesticides as potential endocrine disruptors. The hand book of Environ. Chem., 3: 155-160.

Tahoun, A. M.; Ibrahim, M. A.; Hammouda, Y. F.; Eid, M. S.; Zaki-Eldin, M. A. and Maqoud, F. I. (2008): Effects of age and stocking density on spawning performance of Nile tilapia, O. niloticus (L.) broadstock reared in haps. $8^{\text {th }}$ Inter. Symp. on Tilapia on Aquaculture, 8:329-343.

Takashima, F. and Hibiya, T. (1995): An atlas of fish histology. Normal and pathological features. $2^{\text {nd }}$ ed. Kodansha Ltd. Tokyo, Stuttgart and New York.

Tarek, O.S. (2007): Determination of persistent organic pollutants in sediment and fish the western coast of Alexandria, Egypt. J. Chem. Ecol., 23 (4): 289-302.

Tietz, N.W. (1995): Clinical guide to laboratory tests, $3^{\text {rd }}$ Edition, W.B. Saunders, Co., Philadelphia, pp. 216-217.

Wany, Y. S.; Jaw, G. C.; Tang, H.C.; Lin, T.S. and Chan, Y. L. (1992): Accumulation and release of herbicides Butachlor, Thiobencarb, and Chlomethoxyfen by fish, calm, and shrimp. Bull. Environ. Contam. Toxicol., 48:474-480.

\section{تعطل خصوبة إناث البلطى النيلى المعرضة لمبيد الحشائش البيوتاكلور}

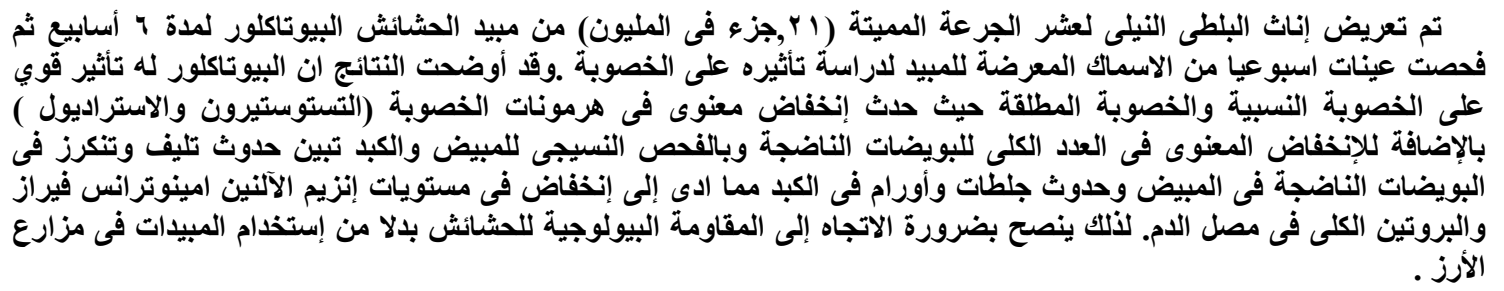

